\title{
Seasonal Feeding Habits of the Wild Boar in a Mediterranean Wetland, the Camargue (Southern France)
}

\begin{abstract}
Maryse DARDAILLON
Dardaillon M., 1987: Seasonal feeding habits of the wild boar in a mediterranean wetland, the Camargue (southern France). Acta theriol., 32, 23: 389-401 [With 2 Tables \& 2 Figs.]

Seasonal feeding habits of wild boars living in a marsh ecosystemthe Camargue, have been investigated by means of both stomach contents analysis and seasonal observations of rooted sites. Analysis of 149 stomach contents, collected during the autumn and winter seasons from 1977-78 through 1982-83, has revealed that wild boars consume a relatively high proportion of animal matter, mainly composed of Vertebrates remains. In early autumn, their diet is composed predominantly of fruits, seeds and grains which appear to be their preferred foods. When these foods becomé scarce, wild boars feed more intensively on underground parts of plants, particularly on bulbs of Scirpus maritimus, but also on green material. Roots and bulbs, which seem to be taken as a second choice, compose the bulk of their diet from late autumn to early summer. During this period, wild boars feed mainly in marshes, meadows and grasslands, and thus live in natural areas. In summer, they migrate into agricultural areas where they rely on crops as major food sources. Availability and phenology of preferred foods therefore greatly account for habitat choices and determine migrations between natural areas and cultivated lands.

[Université Paul Sabatier, U.A. n ${ }^{\circ} 664$ du C.N.R.S., Centre de Recherches en Biologie du Comportement, 118 Route de Narbonne, F-31062 Toulouse Cedex, France]
\end{abstract}

\section{INTRODUCTION}

Wild pigs (Sus scrofa Linnaeus, 1758) are present from Europe to Japan and Indonesia, as well as in Australia, New Zealand, North Africa and the United States. This species thus occupies a tremendous diversity of habitats, including coastal swamps, sand dunes, inland dunes, fresh to brackish marshes, riparian areas, woodlands and most types of forests.

In most areas, wild pigs are known to move according to food availability. So, Lewis (1966), Mackin (1970) and Kurz \& Marchinton (1972) observed range shifts brought about by changes in food supplies. In Tennessee, Belden \& Pelton (1975, 1976), Howe \& Bratton (1976), Bratton (1977) as well as Singer et al. (1981) found that wild boars migrate seasonally between ranges, which are at lower altitudes in the winter than in the summer; they explained these movements by seasonal variations in temperature and food supply. Such altitudinal movements 
have also been observed in various mountains of Eastern Europe (see ref. in Bratton, 1974; and Singer, 1981).

In an earlier paper dealing with seasonal variations in habitat selection and spatial distribution of wild boars living in the Camargue (Dardaillon, 1986), we have described biannual movements between a 1500 ha Reserve and its neighbouring lands. We assumed that these movements resulted from variations in environmental conditions, and particularly in food availability.

On the basis of these results, the object of the present study was to obtain information on seasonal feeding habits of wild boars living in the Camargue. The purpose was to evaluate the influence of variations in availability of preferred food sources on habitat choices and seasonal movements. The subject has been investigated by means of both stomach contents analysis and seasonal observations of rooted sites.

In addition, this study represents a particular interest insofar it has been conducted in a marsh ecosystem - the Camargue, whereas most previous studies have been carried out in forested areas.

\section{STUDY AREA, MATERIAL AND METHODS}

\subsection{Study Area: the Camargue}

The vegetation, characteristic of mediterranean wetlands, forms open landscapes with a mosaic of fresh to brackish marshes, grasslands, thickets of Ulmus campestris, cultivated lands, wet "enganes" (mainly Salicornia sp.), "sansouire" (bareground and dwarf halophytic scrubs of Arthrocnemum glaucum), etc.

The climate, which is of a mediterranean type, is classified as cool and subhumid. There are 24 days per year with minimum temperatures below freezing. Maxima over $30^{\circ} \mathrm{C}$ occur an average on 22 days per year. Wind blows mainly from northwestern direction during winter and spring, and from South-East during autumn. Yearly precipitation averages about $560 \mathrm{~mm}$; snow is rare. $40 \%$ of the rain falls during autumn, while $50 \%$ falls from December through May. Annual water deficiency is $740 \mathrm{~mm}$, of which $70 \%$ occurs during summer (Heurteaux, 1969;. Most marshes and soils are thus completely dried out in summer; they are refilled by autumn rains.

The Camargue is an area of diversified agriculture. However, cereals are grown on nearly $60 \%$ of the 22000 ha of cleared lands (nearly $30 \%$ of the total area in the Camargue). According to the "Registre Général de l'Agriculture", wheat represents $25.1 \%$ (1/4 being hard wheat) of the cereals grown, rice $17 \%$ and maize $12 \%$. Wild boars' damage to crops is primarily confined to these three cereals.

Hunting is a major disturbance for wild boars. Since they are the only big land game, they become the target of hunters from the 1st Sunday of September until the 1st Sunday of January, mainly during "game drives". So, Reser es such as the Camargue National Reserve or the Tour du Valat Reserve appear as refuges. 


\subsection{Material and Methods}

\subsubsection{Rooted Areas}

Sampling area. Seasonal locations and extent of rooted areas were studied in relation to major vegetation cover types on a sampling area of 1047 ha. This sampling area is located on the Tour du Valat Reserve which is a privately owned land with minimal human access. The Reserve covers an area of 1500 ha and is situated in the southeastern part of the Rhône delta. Lying to the East of the brackish water-bodies of the Camargue National Reserve, it is surrounded on its other sides either by cultivated lands or by more or less natural areas.

Mapping of the vegetation. We adopted the classification in six major vegetation

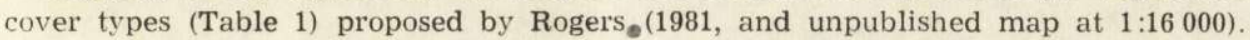

Table 1

Major vegetation cover types: description and estimated percentage of the study area.

\begin{tabular}{|c|c|c|}
\hline Habitat types & Description & of area \\
\hline "Sansouire" & $\begin{array}{l}\text { low-lying lands with halophytic dwarf- } \\
\text { shrubs of Arthrocnemum glaucum and } \\
\text { bare-ground }\end{array}$ & 38.8 \\
\hline "Enganes" & $\begin{array}{l}\text { medium-elevation lands; halophytic dwarf- } \\
\text { shrubs dominated by Salicornia sp. }\end{array}$ & 13.0 \\
\hline $\begin{array}{l}\text { Halophytic } \\
\text { grasslands }\end{array}$ & $\begin{array}{l}\text { high-elevation lands; rich in plant species } \\
\text { (Limonium vulgare, L. bellidifolium, Sali- } \\
\text { cornia fruticosa, Obione portulacoides, etc...) } \\
\text { with scattered Phillyrea angustifolia shrubs }\end{array}$ & 10.2 \\
\hline Scrub grasslands & $\begin{array}{l}\text { on the highest grounds; annual grasses with } \\
\text { Phillyrea angustifolia scrubs or Ulmus cam- } \\
\text { pestris groves }\end{array}$ & 3.8 \\
\hline $\begin{array}{l}\text { Deep and shallow } \\
\text { marshes }\end{array}$ & $\begin{array}{l}\text { deep marshes dominated by Phragmites } \\
\text { communis, or Scirpus maritimus accompa- } \\
\text { nied by P. communis, Typha sp... Shallow } \\
\text { marshes with Scirpus maritimus, Aeluropus } \\
\text { littoralis, Juncus gerardi... Belts with Juncus } \\
\text { maritimus, Tamarix gallica... }\end{array}$ & 27.6 \\
\hline $\begin{array}{l}\text { Fallow or cultivated } \\
\text { farmland }\end{array}$ & $\begin{array}{l}\text { fallow fields, wheat fields and cultivated } \\
\text { grasslands (meadows) }\end{array}$ & 6.6 \\
\hline
\end{tabular}

Their limits, largely delineated by Rogers were traced on a 1:5680 black and white enlargement of the 1:30000 cover of the I.G.N. (1979). These vegetation cover types are representative of those encountered in the natural areas of the Camargue. For computer analysis, the study area was divided by a grid into, squares of $62.5 \mathrm{~m} \times 62.5 \mathrm{~m}\left(3906,25 \mathrm{~m}^{2}\right)$. In each square, major vegetation cover types (from 1 to 4 maximum) were classified in a decreasing order of abundance. The corresponding maps (Dardaillon, 1984, 1986) were obtained by using a digitizing table connected to the microcomputer.

Mapping of rooted sites. Wild boar rooting was defined as visible signs of soil turnover. Field investigations involved recording the plant species consumed in rooted sites and mapping rooted areas on aerial photographs. Once a season in 1982, the sampling area was systematically covered by foot (especially in dense vegetation) or on horseback, in order to obtain a complete examination of all 
parts of the dry lands. The first step consisted in examining the limits of the sampling area and of deep and shallow marshes found within. Then, inside these limits, we made parallel passages spaced according to the vegetation cover: spacing was from 20 to $30 \mathrm{~m}$ in open vegetation, and reduced in scrubs and groves. Each part of the sampling area was thus visited once a season, and the examination of the entire zone required from 20 to 30 consecutive days each time, depending upon the quantity of data gathered. Rooted areas were mapped on a tracing-paper laid over 1:5680 aerial photographs. Maps of the Figure 1 were then obtained by using a digitizing table.

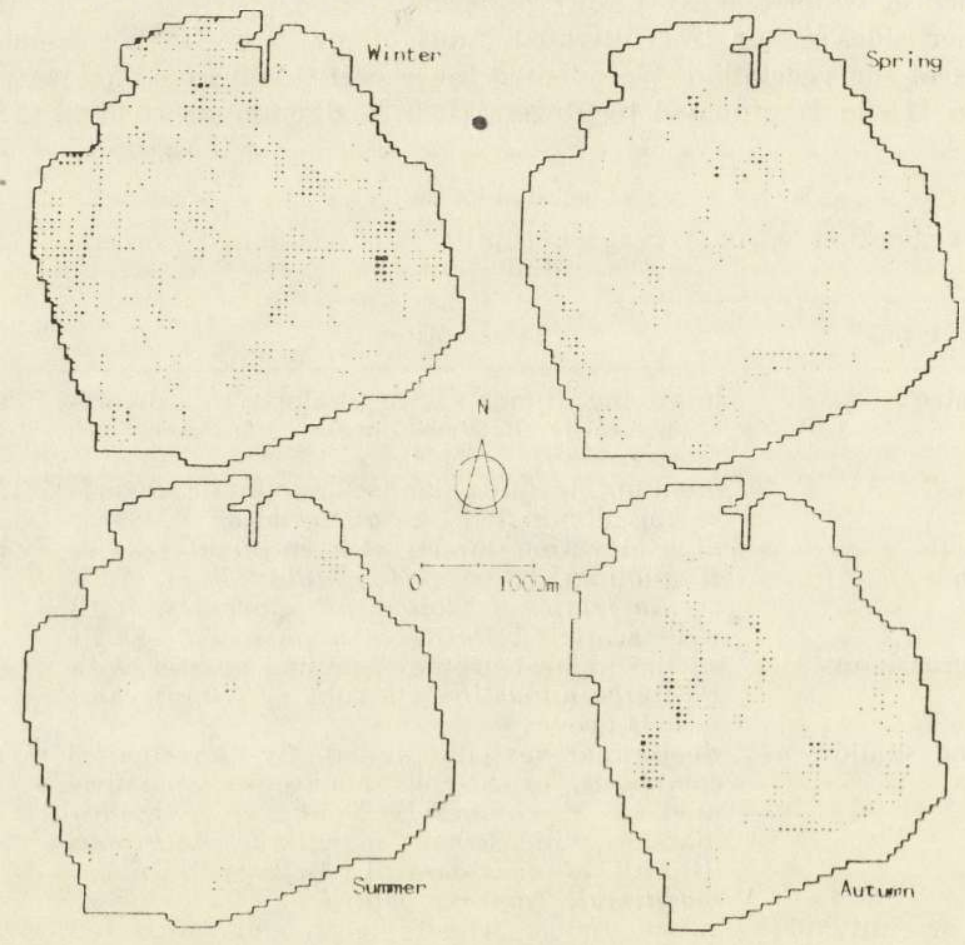

Fig. 1. Seasonal distribution of rooted sites.

2.2.2. Stomach Contents

Collection. 149 stomach contents were collected from wild boars killed during the hunting season, from $1977-78$ through $1982-83$. They were preserved in $10 \%$ formalin solution.

Analysis of stomach contents. Stomach contents were first of all rapidly rinsed through a $0.1 \mathrm{~mm}$ mesh sieve, allowed to drip-dry for about 15 minutes then weighed. In a second step, they were thoroughly washed in a series of 3 sieves of decreasing mesh size $(10.0 \mathrm{~mm}, 2.0 \mathrm{~mm}$ and $1.0 \mathrm{~mm}$, AFNOR-X-11-504, 1970). The three fractions obtained were allowed to drip-dry for about 15 minutes then weighed. Larger pieces of animal matter and vegetation retained in the $10.0 \mathrm{~mm}$ mesh sieve were separated into categories and each category was weighed. 1 to 5 sub-samples were drawn from each of the two other sieves, placed under water 
in a $16 \mathrm{~cm}$ Petri-dish then examined under a variable power ( $4 \mathrm{x}$ to $16 \mathrm{x}$ ) binocular microscope. We used a point-frame analysis method, in which 100 fragments from the sub-sample were chosen using a fixed grid drawn on the bottom of the Petri-dish. The grid was composed of $10 \times 10$ intersecting lines, $1 \mathrm{~cm}$ equidistant from each other. The relative weight of each food item was estimated by its frequency in respect to all food items. Other items were recorded as trace. Food items were identified to the lowest taxon possible and classed as animal matter, underground plant parts, aboveground plant parts and unidentified. Unidentified food items were preserved for future identification.

Data analysis. Frequency of occurrence and percentage composition were determined for overall diet and for each month of sampling. Frequency of occurrence was calculated as the percentage of stomachs containing a particular food item, and percentage composition was determined by using the aggregate percentage method described by Martin et al. (1946).

\section{RESULTS}

\subsection{Rooted Areas}

In the winter, wild boars preferred marshes, meadows and grasslands. In the spring and autumn, they rooted mainly in marshes, while in the summer, farmlands and marshes were the preferred feeding areas (Dardaillon, 1986).

In vegetation types rich in plant species such as grasslands or meadows, it was very difficult to identify food items actually consumed. However, it was relatively easy to identify plant species consumed in other vegetation types. Thus, it was evident that consumption of Scirpus maritimus bulbs, and to a lesser degree of shoots of Phragmites communis, was the main reason for extensive rooting in marshes. On the edges of marshes, other food items frequently identified were roots of Sonchus maritimus. Wild boars also appeared to search for bulbs of Crepis bulbosa which were often very abundant in grasslands.

We have observed that plant phenology greatly influenced forage selection. Consumption of Crepis bulbosa bulbs was noted immediately after these plants grew leaves. Shoots of Phragmites communis were consumed when they were still underground. Soil moisture was also important. In the marshes, rooting was largely dependent upon waterlevel. When marshes were drying up, the extent of mud substrate increased, making underground food readily available.

We have noted many times obvious signs of search for animal matter. Once, it was an abandoned beam which had been displaced; on another occasion, the leaf litter had been rooted in search for invertebrates. After a rainfall, it was frequent to observe emptied snail shells along the wild boar trails. In late spring, when marshes were drying up, fishes were concentrated in some residual pools where wild boars came 
to capture them. During the winter $1981-82$, when fishes living in the canals died by hundreds, we observed many times fresh wild boar tracks around fish remains left on dykes.

\subsection{Analysis of Stomach Contents}

Global dietary composition (Table 2). Global diet was 58.4\% fruits, seeds and grains, 26.4\% underground plant material, $6.2 \%$ green parts of plants, $8.3 \%$ animal food and $0.7 \%$ soil litter.

Animal matter was contained in $83.3 \%$ of the stomachs examined. Vertebrates remains amounted to a more important percentage $(5.4 \%)$ of the composition than invertebrates $(2.1 \%)$ although they were less often present $(42.7 \%$ versus $61.3 \%)$. Fish remains $(3.0 \%)$, snails $(1.6 \%)$ and mammal remains $(1.3 \%)$ were particularly abundant.

Table 2

Global diet of wild boars living in the Camargue, from September through January, according to the analysis of 149 stomach contents collected from 1977-1978 through 1982-1983.

\begin{tabular}{|c|c|c|}
\hline Food item & $\begin{array}{l}\text { Frequency of } \\
\text { occurrence }\end{array}$ & $\begin{array}{l}\text { Percentage } \\
\text { composition }\end{array}$ \\
\hline Total animal food & 83.3 & 8.3 \\
\hline Snails & 44.7 & 1.6 \\
\hline Insects & 34.7 & 0.5 \\
\hline Earthworms & 0.7 & traces \\
\hline (Total Invertebrates) & $(61.3)$ & $(2.1)$ \\
\hline Fishes & 12.7 & 3.0 \\
\hline Mammals & 22.0 & 1.3 \\
\hline Birds & 14.0 . & 0.7 \\
\hline Amphibia & 4.0 & 0.3 \\
\hline Reptiles & 0.7 & traces \\
\hline (Total Vertebrates) & $(42.7)$ & $(5.4)$ \\
\hline Unidentified animal matter & 13.3 & 0.8 \\
\hline Total plant food & 100.0 & 91.0 \\
\hline Leaves, stems, grasses & 82.7 & 6.2 \\
\hline Rice & 46.0 & 27.4 \\
\hline Maize & 28.7 & 20.9 \\
\hline Sorghum & 10.7 & 4.6 \\
\hline Wheat & 14.7 & 4.0 \\
\hline Sunflower & 2.7 & traces \\
\hline Other seeds & 22.0 & 0.5 \\
\hline (Total seeds and grains) & $(77.8)$ & (57.4) \\
\hline Fruits & 8.0 & 1.0 \\
\hline (Total fruits, seeds and grains) & (78.5) & (58.4) \\
\hline (Total aboveground plant material) & (95.3) & $(64.6)$ \\
\hline Shoots of Phragmites communis & 15.3 & 2.8 \\
\hline Total bulbs & 64.0 & 14.4 \\
\hline Scirpus maritimus & 54.7 & 3.3 \\
\hline Crepis bulbosa & 22.7 & 0.8 \\
\hline Other bulbs & 8.0 & 0.3 \\
\hline Roots & 48.0 & 9.2 \\
\hline (Total underground plant material) & (80.7) & (26.4) \\
\hline Soil litter & 8.0 & 0.7 \\
\hline
\end{tabular}


Plant food was found in $100 \%$ of the stomachs and comprised $91.7 \%$ of the average stomach content. This category consisted of underground plant material $(27.1 \%)$ and upper parts of plants (54.6\%). Underground material was $9.1 \%$ roots, $2.8 \%$ shoots of tall-reeds (Phragmites communis) and $14.4 \%$ bulbs, mostly Scirpus maritimus (13.3\%). Upper parts of plants consisted primarily of seeds and grains $(57.4 \%)$ which were found in $77.8 \%$ of the stomachs. Leaves, stems and grasses, present in $82.7 \%$ of the stomachs, amounted to $6.2 \%$ of the average stomach content. Cultivated plants (grains of rice, maize, sorghum and sunflower; grapes; leaves and stems of alfalfa) occurred in $79.2 \%$ of the stomachs analyzed at an average percentage of $58.5 \%$.

Monthly variations in dietary composition (Fig. 2). Fruits, seeds and grains were consumed in autumn. As these foods became scarce, wild boars fed more intensively on underground parts of plants such as tallreed shoots, roots (Sonchus maritimus, Arum italicum, etc.), bulbs (Scirpus maritimus, Crepis bulbosa, etc.). For example, the proportion of Scirpus bulbs increased from $2.3 \%$ in September and $0.3 \%$ in October to $27.1 \%$ and $27.8 \%$ in November and December-January, respect ively. Green vegetation consumption increased from $3.6 \%$ in September to

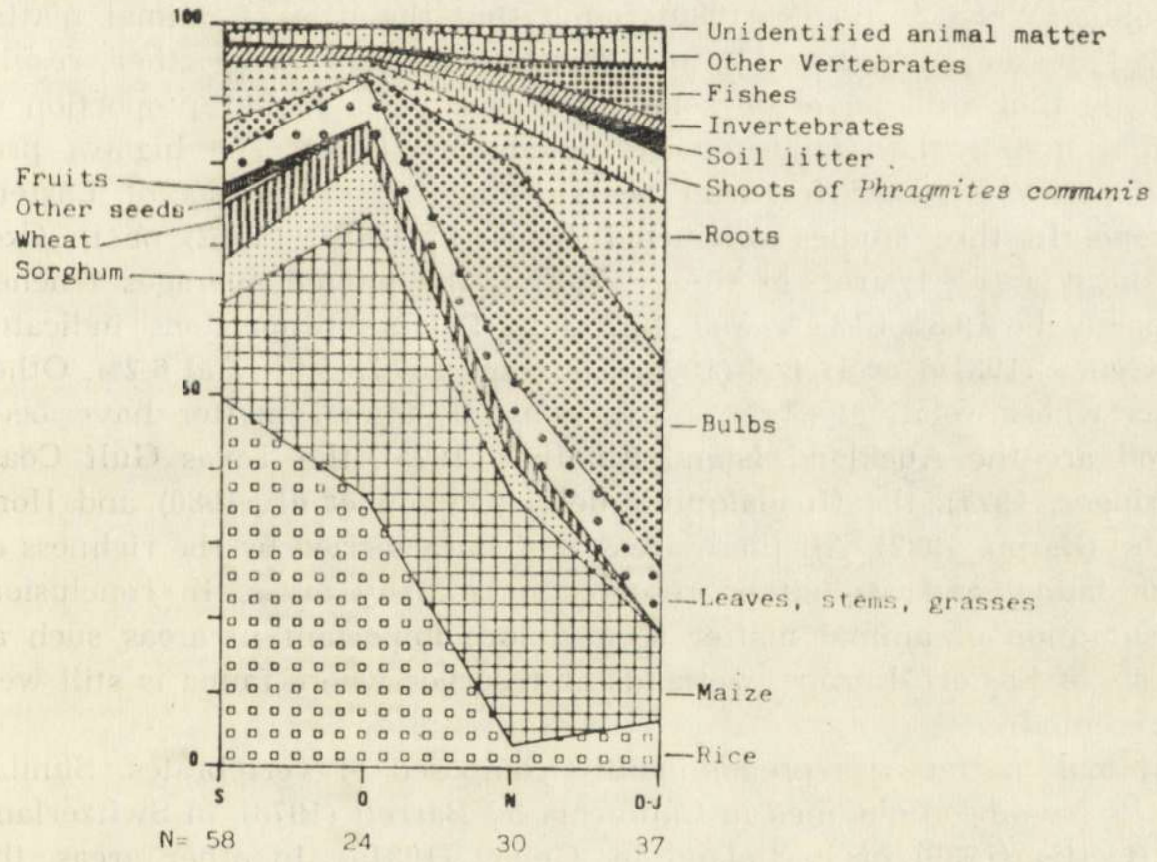

Fig. 2. Monthly variation in the wild boars' diet from September through January. The diagram is based on the percentage composition of major food items found in 149 stomach contents collected from 1977-78 through 1982-83. 
$9.2 \%$ in December-January. Wild boars consumed essentially leaves of Obione portulacoides and Gramineae, which are common in the $\mathrm{Ca}$ margue.

Animal food proportion was $5.6 \%$ in September and 5.0\% in October. By contrast, it was $8.4 \%$ in November and $14.6 \%$ in December-January. The most important increase was observed for fish consumption which was due to the massive fish mortality during the winter $1981-82$.

\section{DISCUSSION AND CONCLUSIONS}

In the Camargue, wild boars feed mainly plants. This result agrees with previous studies conducted in other areas (Briedermann, 1967, 1976; Henry \& Conley, 1972; Asahi, 1975; Scott \& Pelton, 1975; Baker, 1976; Barrett, 1978; Wood \& Roark, 1980; Genov, 1981a; Howe et al., 1981; Holý, 1983; Urtasun, 1983).

Hovever, the proportion of animal matter is particularly high when compared with most results obtained elsewhere. In the Great Smoky Mountains Park, Howe et al. (1981) found a proportion of $2 \%$ vertebrates and invertebrates combined. In California, animal matter comprised only 1.6\% of the total annual volume (Barrett, 1978) and, in South Carolina, Wcod \& Roark (1980) found that the part of animal matter varied seasonally from 0.7 to $2.8 \%$. On the contrary, other results indicate that wild boars do sometimes consume a higher proportion of animal matter than indicated in the above studies. The highest proportions were found for wild boars living in the forests of Eastern Europe. In thre studies conducted either in USSR $(n=2)$ or in Czechoslovakia $(n=1)$ (ref. in Genov, 1981a), the annual averages reached respectively $19.3 \%, 12.4 \%$ and $13.2 \%$. In Poland, proportions indicated by Genov (1981a) or Haber (1966) are respectively $9.0 \%$ and $6.2 \%$. Other areas where relatively high proportions of animal matter have been found are the Auckland Island (Challies, 1975), the Texas Gulf Coast (Springer, 1977), the Guadalquivir delta (Garzón et al., 1980) and Horn Islancl (Baron, 1982). All these areas are characterized by the richness of their fauna, and are either reserves or marshy areas. In conclusion, consumption of animal matter seems more important in areas such as forests of Eastern Europe, wetlands or reserves where fauna is still well represiented.

Animal matter was predominantly composed of vertebrates. Similar results have been obtained in California by Barrett (1978), in Switzerland by Baettig (1980) or in Poland by Genov (1981a). In other areas, the greater part of animal matter consisted of invertebrates (Henry \& Conley, 1972; Wood \& Roark, 1980; Scctt \& Pelton, 1975; Briedermann, 1976; Ackerman et al., 1978; Howe et al., 1981). 
Wild pigs are known to search for invertebrates (Henry \& Conley, 1972; Scott \& Pelton; 1975). For example, they prey on snails (Howe et al., 1978; Morais, 1979), mussels and crabs (Wood \& Roark, 1980) or crayfishes (Henry \& Conley, 1972). With regard to vertebrates consumption, they feed mainly on carrions of birds and mammals (Hanson \& Karstad, 1959; Henry \& Conley, 1972; Pine \& Gerdes, 1973; Baker, 1976; Barrett, 1978; Garzón et; col., 1980; Genov, 1981a), but they can prey on small animals such as salamanders (Scott \& Pelton, 1975; Howe et al., 1978; Garzón et al., 1980), eggs and young of ground nesting birds (Matschke, 1965; Henry, 1969; Challies, 1978), lambs of Merino sheep (Favlcv, 1981; Pavlov et al., 1981; Pavlov \& Home, 1982), etc. In the Guadalquivir delta (Garzón et al., 1980) as well as in the Camargue, wild boars capture fish in drying up marshes. During the winter 1981-82, when fishes living in the Camargue canals died by hundreds, the part of animal matter in the mean stomach content reached $15.9 \%$, of which $11.1 \%$ was constituted by fish. In other areas, Springer (1977) and Genov (1981a) have also found fish in stomach contents. It may be assumed that, in a given area, the proportion of vertebrates in the diet is certainly related with the availability of carrions or of small animals easy to capture such as salamanders, fishes, young of birds and mammals, etc.

As for vegetable matter, the early autumn diet was composed predominantly of fruits, seeds and grains which came to maturity at this time. In most other areas, wild pigs are known to feed on seasonally available fruits, seeds and grains. A literature review made by Genard \& Lescourret (1985) has revealed that diaspores of 52 plant species are known to be consumed by wild boars in Europe. In summer, they may eat grapes and muscadines (Springer, 1977; Wood \& Roark, 1980), blueberries (Belden, 1982, cited in Scott \& Pelton, 1975), apples (Scott \& Pelton, 1975), manzanita berries (Barrett, 1978), oats (Briedermann, 1976; Genov, 1981a), etc. Relative proportion of fruits in the summer diet may be as high as $30-40 \%$ in some areas (Scott \& Pelton, 1975; Springer. 1977; Barrett, 1978), even $80 \%$ as observed in Hawaii by Giffin (1978). In autumn and usually also in winter, wild pigs rely on acorns, beechnuts, chestnuts, hickory nuts, walnuts... as major foods (Briedermann, 1967, 1976; Vericad, 1970; Henry \& Conley, 1972; Pine \& Gerdes, 1973; Scott \& Pelton, 1975; Springer, 1977; Barrett, 1978; Wood \& Roark, 1980; Bratton et al., 1981; Urtasun, 1983). In the Camargue, such food sources are scarce or, as in the case of mast, absent. Consequently, wild boars have to search for other available foods such as seeds of cultivated plants - of which consumption is thereby probably increased. In the literature, various examples show that a good mast crop can result 
in a reduction of the damage done to cultivated fields (Briedermann, 1976; Genov, 1981a).

Thus, in most areas, fruits (including mast), seeds and grains appear as highly preferred foods. However, their consumption is limited since these foods are not only in restricted supply but also available just only during a short time. In the Camargue, wheat is harvested in July, rice from mid-September to mid-October and maize in October. As the harvesting of cultivated crops progresses, the consumption of various grains diminishes whereas the one of underground parts of plants particularly of Scirpus bulbs - increases. As indicated by field observations of the distribution of rooted sites, roots and bulbs compose the bulk of the diet as soon as late autumn and presumably until early summer. Nevertheless, the winter diet also includes green material since rooting in meadows occurs during this season; in addition, stomach contents analysis indicates that the relative proportion of leaves, stems and grasses in the diet increases regularly from $3.6 \%$ in September to $9.2 \%$ in December-January.

In other areas, underground parts of plants are generally consumed mainly during winter, and their proportion in the diet increases in case of low mast production (Scott \& Pelton, 1975). In spring, wild pigs shift generally to a diet composed of green parts of plants (Briedermann, 1967; Pine \& Gerdes, 1973; Scott \& Pelton, 1975; Springer, 1977; Barrett, 1978; Wood \& Roark, 1980, Genov, 1981a). However, in some areas, green material is preferentially consumed as early as in winter (Barrett, 1978) or mainly during this season (Genov, 1981b).

So, roots and bulbs seem to be taken as a second choice, and even as a third choice, in most areas. Their consumption is conditioned by the abundance and the availability of more preferred foods such as fruits, seeds, grains and certain green material, i.s. above ground parts of plants. In the Camargue, roots and bulbs are taken as a second choice even if they compose the bulk of the diet during the greatest part of the year. Wild boars are known to eat also Scripus bulbs in the Belovezha Preserve (ref. in Bratton, 1974) and in the Guadalquivir delta (Garzón et al., 1980). In this second area, which is very similar to the Camargue with regard to the abundance of marshes and scarcity of mast-producing species, Scirpus bulbs represent the preferred food of wild boars, probably because of the absence of nearby cultivated crops.

As in other study areas, wild boars living in the Camargue appear highly seasonal in their food habits. This seasonality is largely determined by availability and phenology of preferred foods, which therefore greatly account for habitat choices and determine biannual migrations between natural areas and cultivated lands (Dardaillon, 1986). 
Acknowledgements: The research was supported by the Foundation "Tour du Valat". Stomach contents collected before 1981 were provided by the Foundation. I wish to thank Prof. R. Campan for his advice and guidance during the course of the study, V. Boy and Dr B. Thon for providing computer programs, J. and D. Smith for correcting the English translation.

\section{REFERENCES}

1. Ackerman B. B., Harmon M. E. \& Singer F. J., 1978: Studies of European wild boar in the Great Smoky Mountains National Park. Part II. Seasonal food habits of European wild boar-1977. Uplands Field Research Laboratory, 1st Annual Report: 94-137.

2. Asahi M., 1975: Stomach contents of wild boars (Sus scrofa leucomystax) in winter. J. Mammal. Soc. Japan, 6: 115-120.

3. Baettig M., 1980: Contribution à la biologie et écologie du sanglier (Sus scrofa L.) dans le canton de Vaud. Travail de dipl me en Zoologie. Univ. Bâle, 1976. Traduction Th. Gilliéron/S A.T., 1-196.

4. Baker J. K., 1976: The feral pig in Hawaii Volcanoes National Park. Proc. Conf. Sci. Natl. Parks, 1: 365-367.

5. Baron J., 1982: Effects of feral hogs (Sus scrofa) on the vegetation of Horn Island, Mississipi. Am. Midland Nat., 107: 202-205.

6. Barrett R. H., 1978: The feral hog on the Dye Creek Ranch, California. Hilgardia, 46: 283-355.

7. Belden R. C. \& Pelton M. R., 1975: European wild hog rooting in the mountains of East Tennessee. Proc. Ann. Conf. S.E. Ass. Game and Fish Comm., 29: $665-671$.

8. Belden, R. C. \& Pelton M. R., 1975: Wallows of the European wild hog in the mountains of East Tennessee. J. Tennessee Acad. Sci., 51: 91-93.

9. Bratton S. P., 1974: The effect of the European wild boar (Sus scrofa) on the high-elevation vernal flora in Great Smoky Mountains National Park. Bull. Torrey Botanical Club, 101: 198-206.

10. Bratton S. P., 1977: The effect of the European wild boar on the flora of the Great Smoky Mountains National Park. [In: "Proc. Symp. Research and Manage. of wild hog populations". Wood G. W., ed.]. Belle W. Baruch Forest Science Institute of Clemson University: 47-52. Georgetown, South Carolina.

11. Briedermann L., 1967: Die Nahrungskomponenten des Schwarzwildes (Sus s. scrofa 1959) in der Mitteleurop"ischen Kulturlandschaft. [In: "Union Internationale des Biologistes du Gibier. Rapports du VIIe Congrès, BeogradLjubljana, 1965) : 207-213.

12. Briedermann L., 1976: Ergebnisse einer Inhaltsanalyse von 665 Wildscheinmagen. Zool. Garten N. F., 46: 157-185.

13. Challies C. N., 1975: Feral pigs (Sus scrofa) on Auckland Island: status, and effects on vegetation and nesting sea birds. N.Z.J. Zool., 2: 479-490.

14. Dardaillon M., 1984: Le sanglier et le milieu camarguais: dynamique coadaptative. Thèse de Doctorat de 3ème cycle, Université Paul Sabatier, Toulouse. $345 \mathrm{pp}$.

15. Dardaillon M., 1986: Seasonal variations in habitat selection and spatial distribution of wild boar (Sus scrofa) in the Camargue, southern France. Behav. Processes, 13: 251-268.

16. Garzón P., Palacios F. \& Ibáñez C., 1980: Primeros datos sobre la alimen- 
tación del jabalí (Sus scrofa baeticus Thomas, 1912) en el Parque Nacional de Doñana. II Reunión Iberoamer. Cons. Zool. Vert.: 466-475.

17. Genard M. \& Lescourret F., 1985: Le sanglier (Sus scrofa scrofa L.) et les diaspores dans le Sud de la France. Rev. Ecol. (Terre Vie), 40: 343-353.

18. Genov P., 1981a: Food composition of wild boar in North-eastern and Western Poland. Acta theriol., 26: 185-205.

19. Genov P., 1981b: Significance of natural biocenoses and agrocenoses as the source of food for wild boars (Sus scrofa L.). Ekol. pol., 29: 117-136.

20. Giffin J., 1978: Ecology of the feral pig on the island of Hawaii. Final Report, Project W-15-3, study $\mathrm{n}^{\circ} 11,1968-1972$. State of Hawaii, Department Land and Natural Resources, Div. Fish and Game. 1-122.

21. Haber A., 1961: Le sanglier en Pologne. Rev. Ecol. (Terre Vie), 108: 74-76.

22. Hanson R. P. \& Karstad L., 1959: Feral swine in the southeastern United States. J. Wildl. Manage., 23: $64-74$.

23. Henry V. G., 1969: Predation on dummy nests of ground-nesting birds in the Southern Appalachians. J. Wildl. Manage., 33: 169-172.

24. Henry V. G. \& Conley R. H., 1972: Fall foods of European wild hogs in the Southern Appalachians. J. Wildl. Manage., 36: 854-860.

25. Heurteaux P., 1969: Recherches sur les rapports des eaux souterraines avec les eaux de surface (étangs, marais, rizières), les sols halomorphes et la vég'tation en Camargue. Thèse de Doctorat d'Etat, Univ. Montpellier. 1-226.

26. Holý J., 1983: Food ecology of boar from the viewpoint of damage to forestry and agriculture. Folia Venatoria, 13: 51-63.

27. Howe T. D. \& Bratton S. P., 1976: Winter rooting activity of the European wild boar in the Great Smoky Mountains National Park. Castanea, 41: 256-264.

28. Howe T. D., Singer F. J. \& Ackerman B. B., 1981: Forage relationships of European wild boar invading northern hardwood forest. J. Wildl. Manage., 45: $748-754$.

29. Kurz J. C. \& Marchinton R. L.: 1972: Radiotelemetry studies of feral hogs in South Carolina. J. Wildl. Manage., 36: 1240-1248.

30. Lewis J. C., 1966: Observations of pen-reared European hogs released for stocking. J. Wildl. Manage., 30: 832-835.

31. Mackin, R., 1970: Dynamics of damage caused by wild boar to different agricultural crops. Acta theriol., 15: 447-458.

32. Martin A. C., Gensch R. H. \& Brown C. P., 1946: Alternative methods in upland gamebird food analysis. J. Wildl. Manage., 10: 8-12.

33. Matschke G. H., 1965: Predation by European wild hogs an dummy nests of ground dwelling birds. Proc. Ann. Conf. S.E. Game and Fish Comm., 19: $154-156$.

34. Morais J. L. P., 1979: Introduçao ao estudo da biologia do javali (Sus scrofa L. 1758) em Portugal. Univ. Lisboa. $1-121$.

35. Pavlov P. M., 1981: Feral pigs- Ungulate predators. J. of Ecology, 4: 132-133.

36. Pavlov P. M., Hone J., Kilgour R. J. \& Pedersen H., 1981: Predation by feral pigs on Merino lambs at Nyngan, New South Wales. Aust. J. Exp. Agric. Anim. Husb., 21: 570-574.

37. Pavlov P. M. \& Hone J., 1982: The behaviour of feral pigs, Sus scrofa, in flocks of lambing ewes. Aust. Wildl. Res., 9: 101-109.

38. Pine D. S. \& Gerdes G. L., 1973: Wild pigs in Monterey County, California. Calif. Fish and Game, 59: 126-137.

39. Rogers P. M., 1981: Ecology of the European wild rabbit Oryctolagus cuniculus 
(L.) in mediterranean habitats. II. Distribution in the landscape of the Camargue, S. France. J. of Applied Ecology, 18: 355-371.

40. Scott C. D. \& Pelton M. R., 1975: Seasonal food habits of the European wild hog in the Great Smoky Mountains National Park. Proc. Ann. Conf. S.E. Ass. Game and Fish Comm., 29: 585-593.

41. Singer F. J., 1981: Wild pig populations in the National Parks. Environmental Management, 5: 263-270.

42. Singer F. J., Otto D. K., Tipton A. R. \& Hable C. P., 1981: Home ranges, movements and habitat use of European wild boar in Tennessee. J. Wildl. Manage., 45: 343-353.

43. Springer M. D., 1977: Ecologic and economic aspects of wild hogs in Texas. [In: "Proc. Symp. Research and Manage. of wild hog populations". Wood G. W., ed.]. Belle W. Baruch Forest Science Institute of Clemson University: 37-46. Georgetown, South Carolina.

44. Urtasun I. L., 1983: Sobre la relación del jabali (Sus scrofa L.) con la agricultura, en Navarra septentrional. XVth Congr. Int. Fauna Cinegética y Silvestre, Trujillo, Spain, 1981: 639-645.

45. Vericad J. R., 1970: Estudio faunístico y biológico de los mamíferos del Pirineo. P. Centr. pir. Biol. exp., 4: 229pp.

46. Wood G. W. \& Roark D. N., 1980: Food habits of feral hogs in coastal South Carolina. J. Wildl. Manage., 44: 506-511.

Received 29 January 1987, Accepted 14 April 1987.

Maryse DARDAILLON

SEZONOWE ZMIANY W POKARMIE DZIKA NA BAGNACH STREFY SRÓDZIEMNOMORSKIEJ : CAMARGUE, POLUDNIOWA FRANCJA

Streszczenie

Badano sezonową zmienność pokarmu dzików (Sus scrofa Linnaeus, 1758) żyjących w ekosystemach bagiennych w Camargue (Tabela 1). Zanalizowano zawartość 149 żołądków (Tabela 2) zebranych jesienią i zimą w latach od 1977/78 do 1982/83. Prowadzono także obserwacje miejsc buchtowania (Ryc. 1). W sezonach jesienno-zimowych dziki zjadały stosunkowo dużo pokarmu zwierzęcego (były to głównie resztki kręgowców). Wczesną jesienią w diecie dzików dominowały owoce, nasiona i zboża, które okazały się pokarmem preferowanym. Gdy te źródła pokarmu wyczerpywały się, zwierzęta w coraz większym stopniu żywiły się podziemnymi częściami roślin (głównie kłączami Scirpus maritimus) oraz ich częściami zielonymi. Korzenie i kłącza, które wydają się być mniej lubianym pokarmem, stanowią podstawę diety dzików od późnej jesieni do początku lata (Ryc. 2). W tym okresie dziki żerują głównie na bagnach i łąkach. Latem natomiast migrują na tereny rolnicze i wówczas rośliny uprawne stanowią ich podstawowe źródło pokarmu. Dostępność i fenologia preferowanych rodzajów pokarmu w dużym stopniu determinuje użytkowanie środowiska przez dziki, a zwłaszcza stymuluje ich dwukrotne w roku migracje między naturalnymi areałami a uprawami rolnymi. 